\title{
Macroeconomic uncertainty and credit default swap spreads
}

\author{
Christopher F Baum* \\ Boston College and DIW Berlin
}

\author{
Chi $\mathrm{Wan}^{\dagger}$ \\ Carleton University
}

March 3, 2010

\begin{abstract}
This paper empirically investigates the impact of macroeconomic uncertainty on the spreads of individual firms' credit default swaps (CDS). While existing literature acknowledges the importance of the levels of macroeconomic factors in determining CDS spreads, we find that the second moments of these factors-macroeconomic uncertainty - have significant explanatory power over and above that of traditional macroeconomic factors such as the risk-free rate and the Treasury term spread.
\end{abstract}

JEL Classification: E32; G12; C23

Keywords: Macroeconomic uncertainty; CDS spreads; Default risk; Credit risk

*Department of Economics, Boston College, 140 Commonwealth Avenue, Chestnut Hill, MA 02467 USA. Tel: +1-617-552-3673, Fax: +1-671-552-2308, E-mail: baum@bc.edu

${ }^{\dagger}$ Department of Economics, Carleton University, 1125 Colonel By Drive, Ottawa, ON, Canada K1S 5B6. Tel: +613-520-2600 x 7454, Fax: +1-613-520-3906, E-mail: chi_wan@carleton.ca 


\section{Introduction}

Over the past decade, the market for credit derivatives has grown tremendously, with the total outstanding notional amount exceeding 62 trillion US dollars by the end of 2008 . The credit default swap (CDS), the most commonly-used credit derivative instrument, has enabled investors to insure against a credit event such as the default of a reference entity (e.g., a bond issuer). Essentially, the CDS buyer makes periodic payments to the CDS seller over the length of the contract in order to receive a contingent payment in the occurrence of default on a bond issued by a corporation or sovereign entity. As a standardized swap contract, CDS can be traded over the counter, which enables investors to hedge or speculate on credit risk in a relatively cost-effective way. CDS spreads fluctuate over time to reflect changes in the creditworthiness of the reference entities.

As documented in Longstaff, Mithal and Neis (2005), Chen, Lesmond and Wei (2007), Houweling, Mentink and Vorst (2005), as well as in Elton, Gruber, Agrawal and Mann (2004), corporate bond yields are largely driven by liquidity factors and tax effects, which might bias quoted bond yields as a gauge of credit risk. In contrast, CDS spreads, expressed in basis points per annum, provide a more direct and readily-available alternative measurement of credit risk. Furthermore, Blanco, Brennan and Marsh (2005), Zhu (2006), and Norden and Weber (2004) have reported that CDS spreads tend to be more responsive to changes in the stock market and firms' credit conditions than bond yields. Consequently, several recent papers, including Houweling and Vorst (2005), Hull, Predescu and White (2004) and Pan and Singleton (2008), have relied on CDS spreads to directly measure the credit risk attributable to issuers' default risk.

A number of recent studies have investigated the empirical determinants of credit spreads. Campbell and Taksler (2003) document that firm-specific return volatility is able to explain about one-third of the variation in bond spreads. More recently, Zhang, Zhou and Zhu (2005) 
further document that equity volatility and jump processes have strong explanatory power in the pricing of CDS. Tang and Yan (2008a) and Bongaerts, de Jong and Driessen (2008) suggest the importance of illiquidity issues in pricing CDS.

The primary objective of this paper is to examine the role of macroeconomic uncertainty in determining credit spreads. Our contribution is twofold. First, we analyse the determinants of CDS spreads: in particular, the role of macroeconomic uncertainty. The effect of macroeconomic uncertainty on CDS spreads is ambiguous. ${ }^{1}$ On the one hand, greater macroeconomic uncertainty may increase the firm's default risk as firms are more likely to be credit constrained. For instance, Korajczyk and Levy (2003) shows that macroeconomic conditions affect a firm's ability to borrow. Baum, Stephan and Talavera (2009) and Baum, Chakraborty and Liu (2010) report strong empirical evidence that macroeconomic uncertainty plays an important role in determining both the level and changes of the firm's leverage. Therefore, uncertainty increases CDS spreads. On the other hand, higher macroeconomic uncertainty drives up the demand for credit risk protection and thus may also reduce CDS spreads. To understand the direction and extent of macroeconomic uncertainty on CDS pricing, we employ several proxies for macroeconomic uncertainty and provide strong empirical evidence of a positive effect of macroeconomic uncertainty on CDS spreads.

Our paper is among the first empirical efforts to evaluate the importance of macroeconomic uncertainty in credit derivative markets. While existing literature acknowledges the importance of the levels of macroeconomic factors in determining CDS spreads, we show that the second moments of these factors - macroeconomic uncertainty - have significant explanatory power over and above that of traditional macroeconomic factors such as the risk-free rate and the Treasury term spread. Our results nicely complement the empirical findings re-

\footnotetext{
1 Tang and Yan (2006) and Tang and Yan (2008b) model firms' default risk as depending on (among other factors) the volatility of aggregate economic growth. However, their model contains a fixed level of volatility, while we focus upon variations in macroeconomic volatility as a factor influencing CDS spreads.
} 
ported by Arnold and Vrugt (2008) and Arshanapalli, d'Ouville, Fabozzi and Switzer (2006). Specifically, Arnold and Vrugt document a positive link between stock market volatility and macroeconomic uncertainty; Arshanapalli et al. show that both stock and bond markets have higher volatility during the period of macroeconomic announcements. One study that is closely related to our paper is Tang and Yan (2008b). Based on structural credit risk models, Tang and Yan examine the impact of market conditions on credit spreads, showing that CDS spreads are decreasing in GDP growth rate, but increasing in GDP growth volatility. However, their model contains a fixed level of volatility, while we focus upon variations in macroeconomic volatility as a factor influencing CDS spreads.

The second contribution of our paper is to carefully control for issuer-level fixed effects in determining credit spreads. Our models control for firms' unobserved heterogeneity (e.g. managerial attributes, corporate governance and the company's executive compensation policies) that may affect firms' credit conditions. For instance, Graham, Harvey and Puri (2009) provide strong evidence that managerial heterogeneity affects corporate financial policies such as acquisitions and capital structure. Moreover, a large body of literature shows, both theoretically (e.g. John and John (1993) and Jin (2002)) and empirically (e.g. Rajgopal and Shevlin (2002), Knopf, Nam and Thornton (2002) and Coles, Daniel and Naveen (2006)), that firms' compensation structures may offer managers with incentives for risk-taking and thus affect firms' credit quality. Our primary finding of a positive effect of macroeconomic uncertainty on credit spreads is largely unaffected after further controlling for issuers' fixed effects.

The reminder of the paper is organized as follows: in the next section, we propose three measures of macroeconomic uncertainty and describe how we construct other variables used in our study. Section III conducts empirical analysis to investigate the effect of macroeconomic uncertainty on credit spreads. Finally, we conclude in Section IV. 


\section{Data sources and construction}

In this section, we detail the data sources used in our study and how variables are constructed.

\section{Identifying macroeconomic uncertainty}

In our investigation, as in Driver, Temple and Urga (2005), Byrne and Davis (2002) and Baum, Caglayan, Ozkan and Talavera (2006), we employ a GARCH model to proxy for macroeconomic uncertainty. We believe that this approach is more appropriate compared to alternatives such as proxies obtained from moving standard deviations of the macroeconomic series (e.g. Ghosal and Loungani (2000)) or survey-based measures based on the dispersion of forecasts (e.g. Graham and Harvey (2001); Schmukler, Mehrez and Kaufmann (1999)). To ensure the robustness of our empirical findings, we construct three proxies for macroeconomic uncertainty from the conditional variance of the GDP growth rate, the index of industrial production and the returns on the S\&P 500 Composite Index. Each of the three measures captures different aspects of macroeconomic uncertainty. The first measure is the conditional variance of the growth rate of a monthly measure of real gross domestic product. We derive the monthly GDP series via the proportional Denton procedure using the monthly index of industrial production as an interpolating variable (see Baum (2001)) from quarterly real GDP (International Financial Statistics series 99BRZF). This measure is designed to reflect the overall uncertainty of the macroeconomic environment. The second measure is derived from the monthly index of industrial production (International Financial Statistics series 66IZF). This measure closely focuses on industrial activity and omits service-sector activity. The last measure, focused on financial market uncertainty, is derived from the monthly returns on the Standard \& Poor's 500 Composite Index (obtained from CRSP Market Indices).

Table 1 reports the specifics of the GARCH models used to construct our proxies for

macroeconomic uncertainty. In each case, a low-order GARCH model fit to monthly data is 
sufficient to capture the dynamics of the series. The predicted conditional volatility series from each model is used as the uncertainty proxy. Table 2 displays the summary statistics of our macroeconomic uncertainty proxies.

\section{Other variables}

In our study, firm-level five-year CDS quotes (in basis points) from the Markit Group are used as a direct proxy of credit spreads. The monthly CDS spreads are calculated as the monthly average over daily closing quotes. Our sample consists of an unbalanced panel of monthly CDS spreads for 527 firms from January 2001 to December 2006, totaling 25279 issuer-month observations: on average four years of monthly observations per issuer. Our dataset spans both the significant credit deterioration experienced by large corporations in 2002 and the improving macroeconomic conditions in the middle of the decade.

Following the prevalent practice in the existing literature, we obtain the following balance variables from COMPUSTAT: market value, defined as the logarithm of monthly closing price multiplied by total shares outstanding; the leverage ratio, measured by total debt divided by total assets; the return on equity, calculated as net income divided by its total equity; and the dividend payout ratio, computed as the dividend payout per share divided by its stock price. We also control for the credit ratings of bond issuers, which are one of the most important factors in pricing credit risk and reflect privileged information processed by rating agencies. Table 3 provides the summary statistics for CDS spreads and other firmlevel control variables included in our sample. Table 4 shows the frequency distribution of our sample, in issuer-months, for Standard \& Poor's domestic long-term issuer credit ratings.

\section{Empirical analysis}

We conduct both pooled OLS and fixed-effect regression analyses to investigate the effects of macroeconomic uncertainty on the determination of CDS spreads. To control for arbitrary 
serial correlation at the individual issuer level, our models are estimated with standard errors clustered by firms with the following econometric specification:

$$
\begin{aligned}
C D S_{i, t}= & \beta_{0}+\beta_{1} M U_{i, t-1}+\beta_{2} \operatorname{Ret}_{i, t-1}+\beta_{3} \sigma_{i, t-1} \\
& +\beta_{4} \log \left(\text { size }_{i, t-1}\right)+\beta_{5} \operatorname{Lev}_{i, t-1}+\beta_{6} \operatorname{ROE}_{i, t-1}+\beta_{7} D I V_{i, t-1} \\
& +\beta_{8} S R_{t-1}+\beta_{9} T S_{t-1}+\sum\left(\gamma_{j} \text { Dating }_{j, i, t}\right)+\varepsilon_{i, t}
\end{aligned}
$$

where $\varepsilon_{t}$ is an idiosyncratic error term. $M U$ is one of the three proxies for macroeconomic uncertainty. Ret is the one-month stock return, while $\sigma$ is the one-month volatility of returns, calculated from daily quotations. size is measured by market value of the firm, while Lev is a measure of financial leverage, $R O E$ is the firm's return on common equity and $D I V$ is the dividend payout ratio. $S R$ is the short-term interest rate measured as three-month Treasury bill rate, while $T S$ is the Treasury term spread, calculated as the difference between ten-year and three-month Treasury rates.

To further control for issuer-specific characteristics in CDS pricing, we employ fixed effect regressions for both the pooled sample (with rating dummies) and several rating-specific subsamples. Our revised empirical specification is:

$$
\begin{aligned}
C D S_{i, t}= & \beta_{0}+\beta_{1} M U_{i, t-1}+\beta_{2} \text { Ret }_{i, t-1}+\beta_{3} \sigma_{i, t-1} \\
& +\beta_{4} \log \left(\text { size }_{i, t-1}\right)+\beta_{5} \text { Lev }_{i, t-1}+\beta_{6} \text { ROE }_{i, t-1}+\beta_{7} D I V_{i, t-1} \\
& +\beta_{8} S R_{t-1}+\beta_{9} T S_{t-1}+\sum\left(\gamma_{j} \text { DRating }_{j, i, t}\right)+\alpha_{i}+\epsilon_{i, t}
\end{aligned}
$$

where $\alpha_{i}$ is an issuer fixed effect used to address unobserved firm heterogeneity.

\section{Issuer pooled OLS results}

We first consider models in which we estimate Equation (1) over the entire sample and separately for rating classes, employing cluster-robust standard errors to allow for arbitrary 
within-issuer correlation. The results in Table 5 are computed from all issuer-month observations with a set of rating dummies (coefficients not reported) for each of the three macroeconomic uncertainty proxies. Each of the uncertainty proxies has a positive and statistically significant effect on the CDS spread. As their scale differs across proxies, the elasticity of the CDS spread with respect to uncertainty is displayed at the foot of the table as $\nu$. A ten percent increase in uncertainty is associated with a $1.0-2.4 \%$ increase in the spread depending on the proxy chosen, with the largest estimated response arising from an increase in uncertainty derived from the S\&P 500 Index return (sprtrn).

Among the control variables, average return, return volatility, market value of the firm, leverage ratio and return on equity all play important roles in the determination of CDS spreads, with little variation in their point estimates across the three models. The signs of these factors are those expected from prior studies. The dividend payout ratio and the two macro factors - the short rate and the term spread - do not play significant roles in these full-sample estimates.

In Tables 6-8, we present similar results derived from models including only certain rating classes. Table 6 provides results for issuers rated AAA, AA, or A, constituting about $40 \%$ of the sample. The results are similar to those of the full sample, with each uncertainty proxy playing an important role in the estimated equation. The elasticity of 0.5 for sprtrn is even larger in this sample of high-rated issuers, implying that a ten percent increase in uncertainty would increase the spread by almost five percent, or about seven basis points. The return on equity is insignificant in this subsample, indicating that profitability may not have that much effect on the firm's ability to service its debt. In contrast to the full-sample results, the dividend payout ratio is now clearly significant, with a positive coefficient, as are the macro factors. A high dividend payout ratio implies a decrease in the firm's cash reserves, and may also indicate that the firm lacks profitable investment opportunities. The 
positive sign of the dividend payout ratio is consistent with Zhang et al. (2005).

Table 7 provides results for BBB-rated issuers, also comprising about $40 \%$ of the sample, with broadly similar results and an elasticity of 0.56 for sprtrn. Interestingly, the included macroeconomic factors - the short rate and the Treasury term spread - exhibit positive and significant coefficients in this rating category as well. The return on equity coefficient is much smaller than that found in the full sample, but in contrast to the highly-rated subsample, it takes on the expected negative sign. The dividend payout ratio does not have a significant effect in any of the BBB models.

Finally, Table 8 presents results for high yield issuers, rated BB or below. In this smaller sample, only uncertainty derived from GDP growth has a statistically significant coefficient, although the estimates for the other two proxies retain their signs. Neither of the macroeconomic factors is significant in this rating class. The effect of a higher return on equity is more pronounced than in the full sample. Interestingly, the dividend payout ratio has negative and significant coefficients in all three models, in contrast to its role in the highlyrated subsample reported in Table 6. For these lower-rated firms, especially those firms whose bonds rated as high yield, our results indicate that investors react positively to the 'signaling' involved with a positive dividend. The predictive power of the dividend signal is stronger when its cost is higher. A firm with the capability to provide cash distributions is indicating its financial strength.

In summary, results from the pooled OLS specification indicate that macroeconomic uncertainty plays a statistically significant and economically meaningful role in determining CDS spreads, over and above the firm-specific factors and macro factors included in the model. 
Issuer fixed effect results

We now turn to models in which we estimate Equation (2) over the entire sample and separately for rating classes, employing issuer-level fixed effects to control for unobserved heterogeneity and cluster-robust standard errors, clustering by issuer. In Table 9, we present results for the entire sample. Macroeconomic uncertainty has a significant effect only for the first proxy, based on GDP growth. All firm-specific control variables are significant with the expected signs, while the macroeconomic control variables are insignificant in these fullsample estimates.

When we turn to models estimated from high-rated (A and above) issuers in Table 10, we find that all three macroeconomic uncertainty proxies again exhibit positive and significant coefficients, with sprtrn displaying the largest elasticity of 0.44 . This implies that a ten percent increase in uncertainty would increase the spread by about $4.4 \%$, or about six basis points. Neither the return on equity nor the dividend payout ratio appear as significant factors for the high-rated issuers, while both macroeconomic factors are strongly significant.

Similar results are apparent for BBB-rated issuers in Table 11, with positive and significant effects of macro uncertainty for all three proxies. The macroeconomic factors - short rate and Treasury term spread-also play important roles for this ratings class. The return on equity variable has significant negative effects in these estimates, while the dividend payout ratio has no meaningful role.

Like the pooled OLS results, the model is less successful for the high yield issuers (rated B and below), with a statistically significant coefficient only appearing on the GDP growth proxy for macroeconomic uncertainty. Neither of the macroeconomic factors are significant in these estimates. Interestingly, neither the dividend payout ratio nor the leverage ratio, which were highly significant for high-yield issuers in the pooled OLS estimates, are significant here.

In summary, results from the fixed effects specifications support those from pooled OLS 
estimation. In both forms of the estimated model, macroeconomic uncertainty plays an important role, particularly with regard to the CDS spreads of more highly-rated issuers.

\section{Conclusions}

This paper empirically investigates the linkage between macroeconomic uncertainty and credit default swap (CDS) spreads using both pooled OLS and firm fixed effects methodologies. Our findings strongly suggest that macroeconomic uncertainty is an important determinants of CDS spreads. While the existing literature considers the importance of the levels of macroeconomic factors in determining CDS spreads, we show that the second moments of these factors - macroeconomic uncertainty - affect CDS spreads even in the presence of traditional macroeconomic factors such as the risk-free rate and the Treasury term spread. Furthermore, we find significant differences in the importance of firm-specific factors across rating classes. The effects of firms' dividend payout ratios and return on equity on CDS spreads differ widely between highly-rated issuers and issuers of 'high yield' securities. Our findings, drawn from a sizable panel dataset, further understanding of determinants of CDS spreads and provide strong empirical evidence of the importance of macroeconomic volatility in credit derivative markets, which should not be ignored in economic policy and credit risk management. Furthermore, given the difficulty of structural models in accurately estimating

and predicting credit spreads (Teixeira (2007)), an interesting direction of future research is to incorporate macroeconomic uncertainty to improve the performance of credit risk models. 


\section{References}

Arnold, I. J. M. and Vrugt, E. B. (2008), 'Fundamental uncertainty and stock market volatility', Applied Financial Economics 18, 1425-1440.

Arshanapalli, B., d'Ouville, E., Fabozzi, F. and Switzer, L. (2006), 'Macroeconomic news effects on conditional volatilities in the bond and stock markets', Applied Financial Economics 16, 377-384.

Baum, C. F. (2001), 'DENTON: Stata module to interpolate a quarterly flow series from annual totals via proportional Denton method', Statistical Software Components, Boston College Department of Economics. http://ideas.repec.org/c/boc/bocode/s422501.html.

Baum, C. F., Caglayan, M., Ozkan, N. and Talavera, O. (2006), 'The impact of macroeconomic uncertainty on non-financial firms' demand for liquidity', Review of Financial Economics 15, 289-304.

Baum, C. F., Chakraborty, A. and Liu, B. (2010), 'The impact of macroeconomic uncertainty on firms' changes in financial leverage', International Journal of Finance $\&$ Economics $15,22-30$.

Baum, C. F., Stephan, A. and Talavera, O. (2009), 'The effects of uncertainty on the leverage of nonfinancial firms', Economic Inquiry 47(2), 216-225.

Blanco, R., Brennan, S. and Marsh, I. W. (2005), 'An empirical analysis of the dynamic relation between investment-grade bonds and credit default swaps', Journal of Finance 60(5), 2255-2281.

Bongaerts, D., de Jong, F. and Driessen, J. (2008), Liquidity and liquidity risk premia in the CDS market, Working paper series, University of Amsterdam.

Byrne, J. P. and Davis, E. P. (2002), Investment and uncertainty in the G7, Discussion papers, National Institute of Economic Research, London.

Campbell, J. Y. and Taksler, G. B. (2003), 'Equity volatility and corporate bond yields', Journal of Finance 58(6), 2321-2350.

Chen, L., Lesmond, D. A. and Wei, J. (2007), 'Corporate yield spreads and bond liquidity', Journal of Finance 62(1), 119-149.

Coles, J. L., Daniel, N. D. and Naveen, L. (2006), 'Managerial incentives and risk-taking', Journal of Financial Economics 79(2), 431 - 468.

Driver, C., Temple, P. and Urga, G. (2005), 'Profitability, capacity, and uncertainty: A model of UK manufacturing investment', Oxford Economic Papers 57(1), 120-141.

Elton, E. J., Gruber, M. J., Agrawal, D. and Mann, C. (2004), 'Factors affecting the valuation of corporate bonds', Journal of Banking $\&$ Finance 28(11), 2747-2767.

Ghosal, V. and Loungani, P. (2000), 'The differential impact of uncertainty on investment in small and large business', The Review of Economics and Statistics 82, 338-349. 
Graham, J. R. and Harvey, C. R. (2001), 'The theory and practice of corporate finance: Evidence from the field', Journal of Financial Economics 60, 187-243.

Graham, J. R., Harvey, C. R. and Puri, M. (2009), Managerial Attitudes and Corporate Actions, Working paper series.

Houweling, P., Mentink, A. and Vorst, T. (2005), 'Comparing possible proxies of corporate bond liquidity', Journal of Banking 6 Finance 29(6), 1331-1358.

Houweling, P. and Vorst, T. (2005), 'Pricing default swaps: Empirical evidence', Journal of International Money and Finance 24(8), 1200-1225.

Hull, J., Predescu, M. and White, A. (2004), 'The relationship between credit default swap spreads, bond yields, and credit rating announcements', Journal of Banking \& Finance 28(11), 2789-2811.

Jin, L. (2002), 'Ceo compensation, diversification, and incentives', Journal of Financial Economics 66(1), 29-63.

John, T. A. and John, K. (1993), 'Top-management compensation and capital structure', Journal of Finance 48(3), 949-974.

Knopf, J. D., Nam, J. and Thornton, J. H. (2002), 'The volatility and price sensitivities of managerial stock option portfolios and corporate hedging', Journal of Finance $57(2), 801-813$.

Korajczyk, R. A. and Levy, A. (2003), 'Capital structure choice: macroeconomic conditions and financial constraints', Journal of Financial Economics 68(1), 75-109.

Longstaff, F. A., Mithal, S. and Neis, E. (2005), 'Corporate yield spreads: Default risk or liquidity? new evidence from the credit default swap market', Journal of Finance 60(5), 2213-2253.

Norden, L. and Weber, M. (2004), 'Informational efficiency of credit default swap and stock markets: The impact of credit rating announcements', Journal of Banking \& Finance 28(11), 2813-2843.

Pan, J. and Singleton, K. J. (2008), 'Default and Recovery Implicit in the Term Structure of Sovereign CDS Spreads', Journal of Finance 63(5), 2345-2384.

Rajgopal, S. and Shevlin, T. (2002), 'Empirical evidence on the relation between stock option compensation and risk taking', Journal of Accounting and Economics 33(2), 145-171.

Schmukler, S., Mehrez, G. and Kaufmann, D. (1999), Predicting currency fluctuations and crises - do resident firms have an informational advantage?, Policy Research Working Paper Series 2259, The World Bank.

Tang, D. Y. and Yan, H. (2006), 'Macroeconomic conditions, firm characteristics, and credit spreads', Journal of Financial Services Research 29(3), 177-210.

Tang, D. Y. and Yan, H. (2008a), Liquidity and Credit Default Swap Spreads, Working paper series, EFA 2008 Conference. 
Tang, D. Y. and Yan, H. (2008b), Market conditions, default risk and credit spreads, Discussion Paper Series 2: Banking and Financial Studies 2008,08, Deutsche Bundesbank, Research Centre.

Teixeira, J. C. A. (2007), 'An empirical analysis of structural models of corporate debt pricing', Applied Financial Economics 17, 1141-1165.

Zhang, B. Y., Zhou, H. and Zhu, H. (2005), Explaining credit default swap spreads with the equity volatility and jump risks of individual firms, Finance and Economics Discussion Series 2005-63, Board of Governors of the Federal Reserve System (U.S.).

Zhu, H. (2006), 'An empirical comparison of credit spreads between the bond market and the credit default swap market', Journal of Financial Services Research 29(3), 211-235. 
Table 1: GARCH Proxies for Macroeconomic Uncertainty, 1995-2006

\begin{tabular}{|c|c|c|c|}
\hline & GDP & IndProdn & SPRetn \\
\hline Constant (mean eqn.) & $\begin{array}{l}-0.001 \\
(-0.95)\end{array}$ & $\begin{array}{c}0.003^{* * *} \\
(4.70)\end{array}$ & $\begin{array}{c}0.009^{*} \\
(2.54)\end{array}$ \\
\hline $\operatorname{ARCH}(1)$ & $\begin{array}{c}0.618^{* *} \\
(2.80)\end{array}$ & $\begin{array}{c}0.158 \\
(1.50)\end{array}$ & $\begin{array}{l}0.143 \\
(1.62)\end{array}$ \\
\hline $\operatorname{ARCH}(2)$ & $\begin{array}{c}-0.632^{* *} \\
(-3.05)\end{array}$ & & \\
\hline $\operatorname{GARCH}(1)$ & $\begin{array}{c}0.928^{* * *} \\
(10.02)\end{array}$ & $\begin{array}{c}-0.848^{* * *} \\
(-4.16)\end{array}$ & $\begin{array}{c}0.852^{\text {*** }} \\
(9.93)\end{array}$ \\
\hline Constant (var. eqn.) & $\begin{array}{l}0.000^{*} \\
(2.17) \\
\end{array}$ & $\begin{array}{c}0.000^{* * *} \\
(4.71)\end{array}$ & $\begin{array}{l}0.000 \\
(0.49)\end{array}$ \\
\hline $\operatorname{AR}(1)$ & & $\begin{array}{c}-0.277^{* *} \\
(-2.70)\end{array}$ & \\
\hline $\mathrm{MA}(1)$ & & $\begin{array}{c}-0.486^{* * *} \\
(-4.91)\end{array}$ & \\
\hline loglikelihood & 383.5 & 383.7 & 263.9 \\
\hline Observations & 144 & 144 & 144 \\
\hline
\end{tabular}


Table 2: Summary Statistics of Macroeconomic Uncertainty Proxies

\begin{tabular}{lrrrrrr}
\hline \hline & $\mathrm{N}$ & mean & Std. Dev. & $\mathrm{p} 25$ & $\mathrm{p} 50$ & $\mathrm{p} 75$ \\
\hline GDP & 144 & 1.926 & 0.969 & 1.229 & 1.626 & 2.351 \\
IndProdn & 144 & 1.680 & 0.206 & 1.546 & 1.675 & 1.812 \\
SPRetn & 144 & 4.143 & 1.329 & 2.869 & 4.216 & 5.106 \\
\hline \hline
\end{tabular}

Note: p25, p50, p75 refer to those percentiles of the empirical distributions.

Table 3: Summary Statistics of Firm-Specific Variables

\begin{tabular}{lrrrrrr}
\hline \hline & $\mathrm{N}$ & mean & Std. Dev. & $\mathrm{p} 25$ & $\mathrm{p} 50$ & $\mathrm{p} 75$ \\
\hline CDS (bps) & 25279 & 138.255 & 285.964 & 30.188 & 55.00 & 131.250 \\
One-month Return (\%) & 25279 & 1.303 & 9.931 & -3.667 & 1.189 & 5.998 \\
One-month Volatility (\%) & 25279 & 8.627 & 5.450 & 5.408 & 7.401 & 10.330 \\
$\log$ (Market Value) & 25279 & 8.988 & 1.312 & 8.056 & 8.954 & 9.809 \\
Leverage Ratio (\%) & 25279 & 29.012 & 20.838 & 13.270 & 23.547 & 39.847 \\
Return on Equity (\%) & 25279 & 1.214 & 5.244 & 1.005 & 1.889 & 2.810 \\
Dividend Payout Ratio (\%) & 25279 & 0.359 & 0.374 & 0 & 0.281 & 0.549 \\
\hline \hline
\end{tabular}

Notes: N represents issuer-months. p25, p50, p75 refer to those percentiles of the empirical distributions.

Table 4: Credit Rating Distribution

\begin{tabular}{lrr}
\hline \hline rating & Freq. & Percent \\
\hline AAA & 383 & 1.926 \\
AA & 1,373 & 5.43 \\
A & 8,247 & 32.62 \\
BBB & 10,393 & 41.11 \\
BB & 3,397 & 13.44 \\
B & 1,336 & 5.29 \\
CCC \& Below & 150 & 0.59 \\
\hline \hline
\end{tabular}

Note: Freq. represents issuer-months. 
Table 5: Determinants of CDS Spreads, 2001-2006 (Pooled OLS)

\begin{tabular}{|c|c|c|c|}
\hline & GDP & IndProdn & sprtrn \\
\hline Macro Uncertainty & $\begin{array}{c}6.817^{* * *} \\
(5.46)\end{array}$ & $\begin{array}{c}11.70^{* * *} \\
(5.06)\end{array}$ & $\begin{array}{l}8.520^{*} \\
(2.29)\end{array}$ \\
\hline Average Return & $\begin{array}{c}-1.498^{* * *} \\
(-3.94)\end{array}$ & $\begin{array}{c}-1.584^{* * *} \\
(-4.19)\end{array}$ & $\begin{array}{c}-1.559^{* * *} \\
(-4.23)\end{array}$ \\
\hline Return Volatility & $\begin{array}{c}9.825^{* * *} \\
(5.80)\end{array}$ & $\begin{array}{c}9.869^{* * *} \\
(5.82)\end{array}$ & $\begin{array}{c}9.212^{* * *} \\
(5.19)\end{array}$ \\
\hline $\log$ (Market Value) & $\begin{array}{c}-13.24^{* * *} \\
(-3.55)\end{array}$ & $\begin{array}{c}-13.28^{* * *} \\
(-3.56)\end{array}$ & $\begin{array}{c}-13.14^{* * *} \\
(-3.57)\end{array}$ \\
\hline Leverage Ratio & $\begin{array}{c}2.365^{* * *} \\
(6.23)\end{array}$ & $\begin{array}{c}2.363^{* * *} \\
(6.22)\end{array}$ & $\begin{array}{c}2.296^{* * *} \\
(5.97)\end{array}$ \\
\hline Return on Equity & $\begin{array}{c}-14.38^{* * *} \\
(-4.20)\end{array}$ & $\begin{array}{c}-14.34^{* * *} \\
(-4.20)\end{array}$ & $\begin{array}{c}-14.32^{* * *} \\
(-4.18)\end{array}$ \\
\hline Dividend Payout Ratio & $\begin{array}{l}-13.08 \\
(-1.40)\end{array}$ & $\begin{array}{l}-13.38 \\
(-1.43)\end{array}$ & $\begin{array}{l}-14.59 \\
(-1.58)\end{array}$ \\
\hline Short Rate & $\begin{array}{l}-4.557 \\
(-0.69)\end{array}$ & $\begin{array}{l}-5.512 \\
(-0.83)\end{array}$ & $\begin{array}{l}-3.760 \\
(-0.54)\end{array}$ \\
\hline Term Spread & $\begin{array}{l}3.944 \\
(0.55)\end{array}$ & $\begin{array}{l}2.083 \\
(0.29)\end{array}$ & $\begin{array}{l}-1.758 \\
(-0.27)\end{array}$ \\
\hline Constant & $\begin{array}{c}1222.8^{* * *} \\
(4.86)\end{array}$ & $\begin{array}{c}1223.8^{* * *} \\
(4.84)\end{array}$ & $\begin{array}{c}1234.8^{* * *} \\
(4.88)\end{array}$ \\
\hline Rating Dummies & Yes & Yes & Yes \\
\hline$\nu$ & $\begin{array}{c}0.097^{* * *} \\
(0.017) \\
\end{array}$ & $\begin{array}{c}0.141^{* * *} \\
(0.029)\end{array}$ & $\begin{array}{l}0.235^{*} \\
(0.106)\end{array}$ \\
\hline No. of obs. & 25279 & 25279 & 25279 \\
\hline No. of clusters & 527 & 527 & 527 \\
\hline Adj. $R^{2}$ & 0.618 & 0.617 & 0.618 \\
\hline
\end{tabular}

$t$ statistics in parentheses

${ }^{*} p<0.05,{ }^{* *} p<0.01,{ }^{* * *} p<0.001$

$\nu$ is the elasticity of the spread with respect to macroeconomic uncertainty. 
Table 6: Determinants of CDS Spreads, 2001-2006 (Pooled OLS: A and Above)

\begin{tabular}{|c|c|c|c|}
\hline & GDP & IndProdn & sprtrn \\
\hline Macro Uncertainty & $\begin{array}{c}1.786^{* * *} \\
(5.11)\end{array}$ & $\begin{array}{c}5.111^{* * *} \\
(4.82)\end{array}$ & $\begin{array}{c}4.993^{* * *} \\
(5.22)\end{array}$ \\
\hline Average Return & $\begin{array}{c}-0.370^{* * *} \\
(-5.41)\end{array}$ & $\begin{array}{c}-0.409^{* * *} \\
(-5.86)\end{array}$ & $\begin{array}{c}-0.430^{* * *} \\
(-6.06)\end{array}$ \\
\hline Return Volatility & $\begin{array}{c}4.427^{* * *} \\
(8.37)\end{array}$ & $\begin{array}{c}4.434^{* * *} \\
(8.39)\end{array}$ & $\begin{array}{c}3.699^{* * *} \\
(5.81)\end{array}$ \\
\hline $\log ($ Market Value) & $\begin{array}{c}-6.392^{* * *} \\
(-4.04)\end{array}$ & $\begin{array}{c}-6.399^{* * *} \\
(-4.05)\end{array}$ & $\begin{array}{c}-6.343^{* * *} \\
(-4.04)\end{array}$ \\
\hline Leverage Ratio & $\begin{array}{c}0.160^{* *} \\
(2.83)\end{array}$ & $\begin{array}{c}0.160^{* *} \\
(2.82)\end{array}$ & $\begin{array}{l}0.139^{*} \\
(2.54)\end{array}$ \\
\hline Return on Equity & $\begin{array}{l}-1.371 \\
(-1.57)\end{array}$ & $\begin{array}{l}-1.358 \\
(-1.55)\end{array}$ & $\begin{array}{l}-1.219 \\
(-1.38)\end{array}$ \\
\hline Dividend Payout Ratio & $\begin{array}{c}19.53^{* *} \\
(2.85)\end{array}$ & $\begin{array}{c}19.38^{* *} \\
(2.83)\end{array}$ & $\begin{array}{l}17.53^{*} \\
(2.51)\end{array}$ \\
\hline Short Rate & $\begin{array}{c}7.526^{\text {*** }} \\
(5.30)\end{array}$ & $\begin{array}{c}7.204^{\text {*** }} \\
(5.13)\end{array}$ & $\begin{array}{c}7.977^{* * *} \\
(5.64)\end{array}$ \\
\hline Term Spread & $\begin{array}{c}12.73^{* * *} \\
(7.10)\end{array}$ & $\begin{array}{c}12.15^{\text {*** }} \\
(6.93)\end{array}$ & $\begin{array}{c}9.573^{* * *} \\
(5.15)\end{array}$ \\
\hline Constant & $\begin{array}{l}14.13 \\
(0.66)\end{array}$ & $\begin{array}{l}11.14 \\
(0.53)\end{array}$ & $\begin{array}{l}8.897 \\
(0.42)\end{array}$ \\
\hline$\nu$ & $\begin{array}{c}0.089^{* * *} \\
(0.016)\end{array}$ & $\begin{array}{c}0.215^{* * *} \\
(0.045)\end{array}$ & $\begin{array}{c}0.497^{* * *} \\
(0.101)\end{array}$ \\
\hline No. of obs. & 10003 & 10003 & 10003 \\
\hline No. of clusters & 214 & 214 & 214 \\
\hline Adj. $R^{2}$ & 0.285 & 0.284 & 0.298 \\
\hline
\end{tabular}

$t$ statistics in parentheses

${ }^{*} p<0.05,{ }^{* *} p<0.01,{ }^{* * *} p<0.001$

$\nu$ is the elasticity of the spread with respect to macroeconomic uncertainty. 
Table 7: Determinants of CDS Spreads, 2001-2006 (Pooled OLS: BBB)

\begin{tabular}{|c|c|c|c|}
\hline & GDP & IndProdn & sprtrn \\
\hline Macro Uncertainty & $\begin{array}{c}3.525^{* * *} \\
(3.79)\end{array}$ & $\begin{array}{c}13.38^{* * *} \\
(5.30)\end{array}$ & $\begin{array}{c}14.42^{* * *} \\
(6.70)\end{array}$ \\
\hline Average Return & $\begin{array}{c}-0.836^{* * *} \\
(-5.36)\end{array}$ & $\begin{array}{c}-0.891^{* * *} \\
(-5.66)\end{array}$ & $\begin{array}{c}-0.893^{* * *} \\
(-5.71)\end{array}$ \\
\hline Return Volatility & $\begin{array}{c}10.13^{* * *} \\
(11.31)\end{array}$ & $\begin{array}{c}10.13^{* * *} \\
(11.31)\end{array}$ & $\begin{array}{c}8.746^{* * *} \\
(9.27)\end{array}$ \\
\hline $\log$ (Market Value) & $\begin{array}{c}-11.45^{* *} \\
(-2.85)\end{array}$ & $\begin{array}{c}-11.48^{* *} \\
(-2.86)\end{array}$ & $\begin{array}{c}-11.63^{* *} \\
(-2.86)\end{array}$ \\
\hline Leverage Ratio & $\begin{array}{c}2.222^{* * *} \\
(6.95)\end{array}$ & $\begin{array}{c}2.216^{* * *} \\
(6.94)\end{array}$ & $\begin{array}{c}1.937^{* * *} \\
(6.08)\end{array}$ \\
\hline Return on Equity & $\begin{array}{c}-5.018^{* * *} \\
(-5.43)\end{array}$ & $\begin{array}{c}-4.987^{* * *} \\
(-5.42)\end{array}$ & $\begin{array}{c}-4.648^{* * *} \\
(-5.18)\end{array}$ \\
\hline Dividend Payout Ratio & $\begin{array}{l}-9.312 \\
(-1.07)\end{array}$ & $\begin{array}{l}-9.427 \\
(-1.08)\end{array}$ & $\begin{array}{l}-9.724 \\
(-1.13)\end{array}$ \\
\hline Short Rate & $\begin{array}{c}15.02^{* * *} \\
(3.86)\end{array}$ & $\begin{array}{c}14.38^{* * *} \\
(3.68)\end{array}$ & $\begin{array}{c}17.57^{\text {*** }} \\
(4.39)\end{array}$ \\
\hline Term Spread & $\begin{array}{c}21.73^{* * *} \\
(5.23)\end{array}$ & $\begin{array}{c}20.59^{* * *} \\
(4.95)\end{array}$ & $\begin{array}{c}14.72^{* * *} \\
(3.64)\end{array}$ \\
\hline Constant & $\begin{array}{l}-21.04 \\
(-0.47)\end{array}$ & $\begin{array}{l}-32.23 \\
(-0.73)\end{array}$ & $\begin{array}{l}-42.16 \\
(-0.93)\end{array}$ \\
\hline$\nu$ & $\begin{array}{c}0.070^{* * *} \\
(0.018)\end{array}$ & $\begin{array}{c}0.225^{* * *} \\
(0.042)\end{array}$ & $\begin{array}{c}0.560^{* * *} \\
(0.082)\end{array}$ \\
\hline No. of obs. & 10393 & 10393 & 10393 \\
\hline No. of clusters & 287 & 287 & 287 \\
\hline Adj. $R^{2}$ & 0.413 & 0.413 & 0.428 \\
\hline
\end{tabular}

$t$ statistics in parentheses

${ }^{*} p<0.05,{ }^{* *} p<0.01,{ }^{* * *} p<0.001$

$\nu$ is the elasticity of the spread with respect to macroeconomic uncertainty. 
Table 8: Determinants of CDS Spreads, 2001-2006 (Pooled OLS: High Yield)

\begin{tabular}{|c|c|c|c|}
\hline & GDP & IndProdn & sprtrn \\
\hline Macro Uncertainty & $\begin{array}{c}32.46^{* * *} \\
(5.13)\end{array}$ & $\begin{array}{l}11.08 \\
(0.91)\end{array}$ & $\begin{array}{l}21.26 \\
(0.96)\end{array}$ \\
\hline Average Return & $\begin{array}{c}-3.470^{* * *} \\
(-4.36)\end{array}$ & $\begin{array}{c}-3.687^{* * *} \\
(-4.55)\end{array}$ & $\begin{array}{c}-3.676^{* * *} \\
(-4.55)\end{array}$ \\
\hline Return Volatility & $\begin{array}{c}12.78^{* *} \\
(2.76)\end{array}$ & $\begin{array}{c}13.01^{* *} \\
(2.81)\end{array}$ & $\begin{array}{c}12.44^{* *} \\
(2.68)\end{array}$ \\
\hline $\log$ (Market Value) & $\begin{array}{l}28.21 \\
(1.39)\end{array}$ & $\begin{array}{l}28.17 \\
(1.39)\end{array}$ & $\begin{array}{l}25.98 \\
(1.25)\end{array}$ \\
\hline Leverage Ratio & $\begin{array}{c}9.655^{* * *} \\
(6.71)\end{array}$ & $\begin{array}{c}9.687^{* * *} \\
(6.70)\end{array}$ & $\begin{array}{c}9.530^{* * *} \\
(6.27)\end{array}$ \\
\hline Return on Equity & $\begin{array}{c}-19.28^{* * *} \\
(-3.99)\end{array}$ & $\begin{array}{c}-19.07^{* * *} \\
(-3.97)\end{array}$ & $\begin{array}{c}-19.08^{* * *} \\
(-3.96)\end{array}$ \\
\hline Dividend Payout Ratio & $\begin{array}{c}-73.54^{*} \\
(-2.22)\end{array}$ & $\begin{array}{c}-74.03^{*} \\
(-2.24)\end{array}$ & $\begin{array}{c}-76.99^{*} \\
(-2.33)\end{array}$ \\
\hline Short Rate & $\begin{array}{l}-31.15 \\
(-0.91)\end{array}$ & $\begin{array}{l}-31.35 \\
(-0.92)\end{array}$ & $\begin{array}{l}-19.29 \\
(-0.46)\end{array}$ \\
\hline Term Spread & $\begin{array}{l}-26.84 \\
(-0.69)\end{array}$ & $\begin{array}{l}-30.58 \\
(-0.78)\end{array}$ & $\begin{array}{l}-30.97 \\
(-0.79)\end{array}$ \\
\hline Constant & $\begin{array}{l}-326.1 \\
(-1.56)\end{array}$ & $\begin{array}{l}-275.9 \\
(-1.31)\end{array}$ & $\begin{array}{l}-330.0 \\
(-1.48)\end{array}$ \\
\hline$\nu$ & $\begin{array}{c}0.153^{* * *} \\
(0.026)\end{array}$ & $\begin{array}{c}0.044 \\
(0.049)\end{array}$ & $\begin{array}{c}0.170 \\
(0.181)\end{array}$ \\
\hline $\begin{array}{l}\text { No. of obs. } \\
\text { No. of clusters } \\
\text { Adj. } R^{2}\end{array}$ & $\begin{array}{c}4883 \\
169 \\
0.523\end{array}$ & $\begin{array}{c}4883 \\
169 \\
0.521\end{array}$ & $\begin{array}{c}4883 \\
169 \\
0.522\end{array}$ \\
\hline
\end{tabular}

$t$ statistics in parentheses

${ }^{*} p<0.05,{ }^{* *} p<0.01,{ }^{* * *} p<0.001$

$\nu$ is the elasticity of the spread with respect to macroeconomic uncertainty. 
Table 9: Determinants of CDS Spreads, 2001-2006 (Issuer Fixed Effects)

\begin{tabular}{|c|c|c|c|}
\hline & GDP & IndProdn & sprtrn \\
\hline Macro Uncertainty & $\begin{array}{c}5.865^{* * *} \\
(6.06)\end{array}$ & $\begin{array}{l}3.242 \\
(1.61)\end{array}$ & $\begin{array}{l}-1.321 \\
(-0.40)\end{array}$ \\
\hline Average Return & $\begin{array}{c}-1.500^{\text {*** }} \\
(-4.92)\end{array}$ & $\begin{array}{c}-1.574^{* * *} \\
(-5.18)\end{array}$ & $\begin{array}{c}-1.578^{* * *} \\
(-5.15)\end{array}$ \\
\hline Return Volatility & $\begin{array}{c}6.862^{* * *} \\
(4.79)\end{array}$ & $\begin{array}{c}6.908^{* * *} \\
(4.82)\end{array}$ & $\begin{array}{c}6.995^{* * *} \\
(4.44)\end{array}$ \\
\hline $\log$ (Market Value) & $\begin{array}{c}-92.01^{* * *} \\
(-4.57)\end{array}$ & $\begin{array}{c}-92.42^{* * *} \\
(-4.58)\end{array}$ & $\begin{array}{c}-94.22^{* * *} \\
(-4.24)\end{array}$ \\
\hline Leverage Ratio & $\begin{array}{c}4.059^{* * *} \\
(6.03)\end{array}$ & $\begin{array}{c}4.057^{* * *} \\
(6.02)\end{array}$ & $\begin{array}{c}4.065^{* * *} \\
(6.04)\end{array}$ \\
\hline Return on Equity & $\begin{array}{c}-8.284^{* * *} \\
(-4.59)\end{array}$ & $\begin{array}{c}-8.237^{* * *} \\
(-4.57)\end{array}$ & $\begin{array}{c}-8.223^{* * *} \\
(-4.59)\end{array}$ \\
\hline Dividend Payout Ratio & $\begin{array}{c}-22.90^{*} \\
(-2.08)\end{array}$ & $\begin{array}{c}-23.94^{*} \\
(-2.17)\end{array}$ & $\begin{array}{c}-24.16^{*} \\
(-2.16)\end{array}$ \\
\hline Short Rate & $\begin{array}{l}7.860 \\
(1.30)\end{array}$ & $\begin{array}{l}7.173 \\
(1.19)\end{array}$ & $\begin{array}{l}7.015 \\
(1.15)\end{array}$ \\
\hline Term Spread & $\begin{array}{l}3.949 \\
(0.66)\end{array}$ & $\begin{array}{l}2.483 \\
(0.41)\end{array}$ & $\begin{array}{l}2.984 \\
(0.51)\end{array}$ \\
\hline Constant & $\begin{array}{c}1932.6^{* *} \\
(3.30)\end{array}$ & $\begin{array}{c}1948.2^{* * *} \\
(3.33)\end{array}$ & $\begin{array}{c}1968.3^{* * *} \\
(3.32)\end{array}$ \\
\hline Rating Dummies & Yes & Yes & Yes \\
\hline$\nu$ & $\begin{array}{c}0.084^{* * *} \\
(0.014)\end{array}$ & $\begin{array}{c}0.039 \\
(0.024) \\
\end{array}$ & $\begin{array}{c}-0.036 \\
(0.090)\end{array}$ \\
\hline No. of obs. & 25279 & 25279 & 25279 \\
\hline No. of clusters & 527 & 527 & 527 \\
\hline Adj. $R^{2}$ & 0.360 & 0.359 & 0.359 \\
\hline
\end{tabular}

$t$ statistics in parentheses

${ }^{*} p<0.05,{ }^{* *} p<0.01,{ }^{* * *} p<0.001$

$\nu$ is the elasticity of the spread with respect to macroeconomic uncertainty. 
Table 10: Determinants of CDS Spreads, 2001-2006 (Issuer Fixed Effects: A and Above)

\begin{tabular}{|c|c|c|c|}
\hline & GDP & IndProdn & sprtrn \\
\hline Macro Uncertainty & $\begin{array}{c}1.774^{* * *} \\
(5.98)\end{array}$ & $\begin{array}{c}3.015^{* * *} \\
(3.46)\end{array}$ & $\begin{array}{c}4.432^{* * *} \\
(7.44)\end{array}$ \\
\hline Average Return & $\begin{array}{c}-0.392^{* * *} \\
(-7.59)\end{array}$ & $\begin{array}{c}-0.431^{* * *} \\
(-7.82)\end{array}$ & $\begin{array}{c}-0.449^{* * *} \\
(-8.23)\end{array}$ \\
\hline Return Volatility & $\begin{array}{c}2.773^{* * *} \\
(9.95)\end{array}$ & $\begin{array}{c}2.787^{* * *} \\
(9.98)\end{array}$ & $\begin{array}{c}2.160^{* * *} \\
(7.31)\end{array}$ \\
\hline $\log ($ Market Value) & $\begin{array}{c}-23.68^{* * *} \\
(-5.90)\end{array}$ & $\begin{array}{c}-23.71^{* * *} \\
(-5.88)\end{array}$ & $\begin{array}{c}-15.04^{* * *} \\
(-3.60)\end{array}$ \\
\hline Leverage Ratio & $\begin{array}{l}0.634^{*} \\
(2.50)\end{array}$ & $\begin{array}{l}0.635^{*} \\
(2.50)\end{array}$ & $\begin{array}{c}0.698^{* *} \\
(2.83)\end{array}$ \\
\hline Return on Equity & $\begin{array}{l}-0.791 \\
(-1.88)\end{array}$ & $\begin{array}{l}-0.783 \\
(-1.85)\end{array}$ & $\begin{array}{l}-0.649 \\
(-1.61)\end{array}$ \\
\hline Dividend Payout Ratio & $\begin{array}{l}2.298 \\
(0.57)\end{array}$ & $\begin{array}{l}1.762 \\
(0.44)\end{array}$ & $\begin{array}{l}4.228 \\
(1.12)\end{array}$ \\
\hline Short Rate & $\begin{array}{c}5.188^{* * *} \\
(4.16)\end{array}$ & $\begin{array}{c}4.886^{\text {*** }} \\
(3.91)\end{array}$ & $\begin{array}{c}5.421^{* * *} \\
(4.25)\end{array}$ \\
\hline Term Spread & $\begin{array}{c}8.402^{* * *} \\
(5.61)\end{array}$ & $\begin{array}{c}7.853^{\text {*** }} \\
(5.26)\end{array}$ & $\begin{array}{c}6.269^{* * *} \\
(4.44)\end{array}$ \\
\hline Constant & $\begin{array}{c}206.3^{* * *} \\
(4.57)\end{array}$ & $\begin{array}{c}207.1^{* * *} \\
(4.54)\end{array}$ & $\begin{array}{l}112.7^{*} \\
(2.38)\end{array}$ \\
\hline$\nu$ & $\begin{array}{c}0.088^{* * *} \\
(0.015)\end{array}$ & $\begin{array}{c}0.127^{* * *} \\
(0.037)\end{array}$ & $\begin{array}{c}0.442^{* * *} \\
(0.059)\end{array}$ \\
\hline No. of Obs. & 10003 & 10003 & 10003 \\
\hline No. of clusters & 214 & 214 & 214 \\
\hline Adj. $R^{2}$ & 0.283 & 0.281 & 0.299 \\
\hline
\end{tabular}

$t$ statistics in parentheses

${ }^{*} p<0.05,{ }^{* *} p<0.01,{ }^{* * *} p<0.001$

$\nu$ is the elasticity of the spread with respect to macroeconomic uncertainty. 
Table 11: Determinants of CDS Spreads, 2001-2006 (Issuer Fixed Effects: BBB)

\begin{tabular}{|c|c|c|c|}
\hline & GDP & IndProdn & sprtrn \\
\hline Macro Uncertainty & $\begin{array}{c}3.580^{* * *} \\
(4.69)\end{array}$ & $\begin{array}{c}5.550^{* *} \\
(2.99)\end{array}$ & $\begin{array}{c}8.453^{* * *} \\
(3.53)\end{array}$ \\
\hline Average Return & $\begin{array}{c}-0.861^{* * *} \\
(-6.57)\end{array}$ & $\begin{array}{c}-0.913^{* * *} \\
(-6.87)\end{array}$ & $\begin{array}{c}-0.902^{* * *} \\
(-6.77)\end{array}$ \\
\hline Return Volatility & $\begin{array}{c}6.524^{* * *} \\
(8.80)\end{array}$ & $\begin{array}{c}6.536^{* * *} \\
(8.81)\end{array}$ & $\begin{array}{c}5.858^{* * *} \\
(7.20)\end{array}$ \\
\hline $\log$ (Market Value) & $\begin{array}{c}-57.29^{* * *} \\
(-4.31)\end{array}$ & $\begin{array}{c}-57.36^{* * *} \\
(-4.31)\end{array}$ & $\begin{array}{c}-46.55^{* * *} \\
(-3.45)\end{array}$ \\
\hline Leverage Ratio & $\begin{array}{c}2.494^{* * *} \\
(3.72)\end{array}$ & $\begin{array}{c}2.487^{* * *} \\
(3.71)\end{array}$ & $\begin{array}{c}2.294^{* * *} \\
(3.44)\end{array}$ \\
\hline Return on Equity & $\begin{array}{c}-1.931^{\text {*** }} \\
(-3.83)\end{array}$ & $\begin{array}{c}-1.905^{* * *} \\
(-3.80)\end{array}$ & $\begin{array}{c}-1.883^{* * *} \\
(-3.72)\end{array}$ \\
\hline Dividend Payout Ratio & $\begin{array}{l}9.468 \\
(0.79)\end{array}$ & $\begin{array}{l}8.945 \\
(0.75)\end{array}$ & $\begin{array}{l}10.74 \\
(0.88)\end{array}$ \\
\hline Short Rate & $\begin{array}{c}9.673^{* *} \\
(2.75)\end{array}$ & $\begin{array}{l}9.144^{*} \\
(2.59)\end{array}$ & $\begin{array}{c}11.16^{* *} \\
(3.14)\end{array}$ \\
\hline Term Spread & $\begin{array}{c}11.14^{* *} \\
(2.94)\end{array}$ & $\begin{array}{c}10.14^{* *} \\
(2.67)\end{array}$ & $\begin{array}{l}8.672^{*} \\
(2.33)\end{array}$ \\
\hline Constant & $\begin{array}{c}420.7^{* * *} \\
(3.39)\end{array}$ & $\begin{array}{c}422.6^{* * *} \\
(3.39)\end{array}$ & $\begin{array}{l}313.6^{*} \\
(2.47)\end{array}$ \\
\hline$\nu$ & $\begin{array}{c}0.071^{* * *} \\
(0.015)\end{array}$ & $\begin{array}{l}0.093^{* *} \\
(0.031)\end{array}$ & $\begin{array}{c}0.328^{* * *} \\
(0.093)\end{array}$ \\
\hline $\begin{array}{l}\text { No. of obs. } \\
\text { No. of clusters } \\
\text { Adj. } R^{2}\end{array}$ & $\begin{array}{c}10393 \\
287 \\
0.368\end{array}$ & $\begin{array}{c}10393 \\
287 \\
0.367\end{array}$ & $\begin{array}{c}10393 \\
287 \\
0.375\end{array}$ \\
\hline
\end{tabular}

$t$ statistics in parentheses

${ }^{*} p<0.05,{ }^{* *} p<0.01,{ }^{* * *} p<0.001$

$\nu$ is the elasticity of the spread with respect to macroeconomic uncertainty. 
Table 12: Determinants of CDS Spreads, 2001-2006 (Issuer Fixed Effects: High Yield)

\begin{tabular}{|c|c|c|c|}
\hline & GDP & IndProdn & sprtrn \\
\hline Macro Uncertainty & $\begin{array}{c}25.60^{* * *} \\
(5.13)\end{array}$ & $\begin{array}{l}-2.913 \\
(-0.23)\end{array}$ & $\begin{array}{l}23.25 \\
(1.00)\end{array}$ \\
\hline Average Return & $\begin{array}{c}-3.362^{* * *} \\
(-5.48)\end{array}$ & $\begin{array}{c}-3.542^{* * *} \\
(-5.66)\end{array}$ & $\begin{array}{c}-3.503^{* * *} \\
(-5.45)\end{array}$ \\
\hline Return Volatility & $\begin{array}{l}8.170^{*} \\
(2.35)\end{array}$ & $\begin{array}{l}8.351^{*} \\
(2.41)\end{array}$ & $\begin{array}{l}7.876^{*} \\
(2.38)\end{array}$ \\
\hline $\log$ (Market Value) & $\begin{array}{c}-362.4^{* *} \\
(-3.25)\end{array}$ & $\begin{array}{c}-364.9^{* *} \\
(-3.26)\end{array}$ & $\begin{array}{c}-367.9^{* *} \\
(-3.31)\end{array}$ \\
\hline Leverage Ratio & $\begin{array}{l}0.602 \\
(0.19)\end{array}$ & $\begin{array}{l}0.625 \\
(0.20)\end{array}$ & $\begin{array}{l}-0.160 \\
(-0.06)\end{array}$ \\
\hline Return on Equity & $\begin{array}{c}-9.792^{* * *} \\
(-3.66)\end{array}$ & $\begin{array}{c}-9.569^{* * *} \\
(-3.61)\end{array}$ & $\begin{array}{c}-9.453^{* * *} \\
(-3.52)\end{array}$ \\
\hline Dividend Payout Ratio & $\begin{array}{l}-69.79 \\
(-1.57)\end{array}$ & $\begin{array}{l}-72.05 \\
(-1.63)\end{array}$ & $\begin{array}{l}-77.93 \\
(-1.90)\end{array}$ \\
\hline Short Rate & $\begin{array}{l}23.18 \\
(0.68)\end{array}$ & $\begin{array}{l}23.45 \\
(0.69)\end{array}$ & $\begin{array}{l}36.98 \\
(0.95)\end{array}$ \\
\hline Term Spread & $\begin{array}{l}12.54 \\
(0.35)\end{array}$ & $\begin{array}{l}9.912 \\
(0.28)\end{array}$ & $\begin{array}{l}12.70 \\
(0.34)\end{array}$ \\
\hline Constant & $\begin{array}{c}3023.6^{* *} \\
(3.09)\end{array}$ & $\begin{array}{c}3101.0^{* *} \\
(3.14)\end{array}$ & $\begin{array}{c}3041.4^{* *} \\
(2.99)\end{array}$ \\
\hline$\nu$ & $\begin{array}{c}0.121^{* * *} \\
(0.024)\end{array}$ & $\begin{array}{l}-0.012 \\
(0.050)\end{array}$ & $\begin{array}{c}0.186 \\
(0.187)\end{array}$ \\
\hline $\begin{array}{l}\text { No. of obs. } \\
\text { No. of clusters } \\
\text { Adj. } R^{2}\end{array}$ & $\begin{array}{c}4883 \\
169 \\
0.366\end{array}$ & $\begin{array}{c}4883 \\
169 \\
0.363\end{array}$ & $\begin{array}{c}4883 \\
169 \\
0.365\end{array}$ \\
\hline
\end{tabular}

$t$ statistics in parentheses

${ }^{*} p<0.05,{ }^{* *} p<0.01,{ }^{* * *} p<0.001$

$\nu$ is the elasticity of the spread with respect to macroeconomic uncertainty. 